\title{
Organization of left-right coordination of neuronal activity in the mammalian spinal cord locomotor CPG: insights from computational modeling
}

\author{
Ilya A Rybak ${ }^{*}$, Natalia A Shevtsova ${ }^{1}$, Adolfo E Talpalar², Sergey N Markin ${ }^{1}$, Ronald M Harris-Warrick ${ }^{3}$, Ole Kiehn²
}

From The Twenty Third Annual Computational Neuroscience Meeting: CNS*2014

Québec City, Canada. 26-31 July 2014

Different gaits of locomotion in mammals are based on the appropriate coordination of neuronal activity in the spinal cord controlling movements of left and right limbs. This left-right coordination is provided in the spinal cord by the commissural interneurons (CINs) whose axons cross the midline and affect neural circuits on the contralateral side of the cord. Several types of CINs have been genetically identified, including the excitatory V3 CINs and the inhibitory $\left(\mathrm{VO}_{\mathrm{D}}\right)$ and excitatory $\left(\mathrm{VO}_{\mathrm{V}}\right) \mathrm{VO}$ CINs. Talpalar et al. [1] recently demonstrated that (a) ablation of both V0 CIN types leads to a left-right synchronized, "hopping" activity at all locomotor frequencies, whereas (b) selective ablation of the excitatory $\mathrm{VO}_{\mathrm{V}}$ CINs maintains alternation at low frequencies but switches to synchronized activity at high frequencies while (c) ablation of only the inhibitory $\mathrm{V}_{\mathrm{D}} \mathrm{CINs}$ leads to a lack of left-right alternation at low frequencies, but maintains alternation at high frequencies. The genetically identified, ipsilaterally projecting excitatory V2a interneurons are recruited with an increase in locomotor speed [2] and contribute to leftright alternation at high locomotor frequencies [3,4]. Our objective was to construct and analyze a computational model of the bilaterally interacting central pattern generators (CPGs) that could reproduce and explain these findings.

In our model, the CPG on each side of the cord consisted of flexor and extensor half-centers. Each neural population, including the half-centers and CIN populations, consisted of 50-200 neurons modeled in the Hodgkin-Huxley style.

\footnotetext{
* Correspondence: rybak@drexel.edu

'Department of Neurobiology and Anatomy, Drexel University College of Medicine, Philadelphia, PA 19129, USA

Full list of author information is available at the end of the article
}

The intrinsic bursting of CPG neurons was based on a persistent sodium current in these neurons.

During model construction, we assumed that left-right coordination of activity depends on the balance between the three CIN pathways providing interactions between the left and right CPGs: the V3-mediated pathway that supports left-right synchronization and the $\mathrm{VO}_{\mathrm{D}^{-}}$and $\mathrm{VO}_{\mathrm{V}^{-}}$ mediated pathways that provide left-right alternation. The activity of each (left and right) inhibitory $\mathrm{VO}_{\mathrm{D}}$ population was driven by the ipsilateral flexor half-center. The recruitment of $\mathrm{V}_{\mathrm{D}}$ neurons was progressively reduced with an increase in locomotor speed, because of the reduction of burst amplitude. The left and right $\mathrm{V} 0_{\mathrm{V}}$ pathways could be organized in two ways: (1) the $\mathrm{V}_{\mathrm{V}}$ activity on each side was driven by the ipsilateral flexor half-center and its action on contralateral circuits was mediated by an inhibitory population, or (2) the $\mathrm{V}_{\mathrm{V}}$ activity was driven by the ipsilateral extensor half-center and it excited the contralateral circuits. In any case, the $\mathrm{V}_{\mathrm{V}}$ activation was mediated by the ipsilateral V2a neurons progressively recruited with increasing locomotor speed.

The model demonstrates: (1) a left-right alternating pattern under control conditions; (2) a synchronized hopping pattern at any frequency after removing both the V0 populations; (3) a synchronized pattern at low frequencies with alternation at high frequencies after removing the $\mathrm{V}_{0}$ populations; (4) an alternating pattern at low frequencies with synchronized hopping at high frequencies after removing either $\mathrm{V}_{\mathrm{V}}$ or $\mathrm{V} 2 \mathrm{a}$ populations. The model closely reproduces and suggests an explanation for the experimental data of Talpalar et al. [1], Zhong et al. [2], and Crone et al. [3,4], proposes the organization of commissural interactions in the spinal cord 
defining the left-right alternation at different locomotor speeds, and generates predictions for future experimental investigations.

\section{Acknowledgements}

Supported by NIH grant R01NS7323, Swedish Research Council, and Torsten and Ragnar Söderbergs foundations.

\section{Authors' details}

'Department of Neurobiology and Anatomy, Drexel University College of Medicine, Philadelphia, PA 19129, USA. ²Department of Neuroscience, Karolinska Institute, Stockholm, 17177, Sweden. ${ }^{3}$ Department of

Neurobiology and Behavior, Cornell University, Ithaca, NY 14853, USA.

Published: 21 July 2014

\section{References}

1. Talpalar AE, Bouvier J, Borgius L, Fortin G, Pierani A, Kiehn O: Dual-mode operation of neuronal networks involved in left-right alternation. Nature 2013, 500(7460):85-88.

2. Zhong G, Sharma K, Harris-Warrick RM: Frequency-dependent recruitment of V2a interneurons during fictive locomotion in the mouse spinal cord. Nat Commun 2011, 2:274.

3. Crone SA, Quinlan KA, Zagoraiou L, Droho S, Restrepo CE, Lundfald L, Endo T, Setlak J, Jessell TM, Kiehn O, Sharma K: Genetic ablation of V2a ipsilateral interneurons disrupts left-right locomotor coordination in mammalian spinal cord. Neuron 2008, 60(1):70-83.

4. Crone SA, Zhong G, Harris-Warrick R, Sharma K: In mice lacking V2a interneurons, gait depends on speed of locomotion. J Neurosci 2009, 29(21):7098-109.

doi:10.1186/1471-2202-15-S1-010

Cite this article as: Rybak et al:: Organization of left-right coordination of neuronal activity in the mammalian spinal cord locomotor CPG: insights from computational modeling. BMC Neuroscience 2014

15(Suppl 1):010.

\section{Submit your next manuscript to BioMed Central and take full advantage of:}

- Convenient online submission

- Thorough peer review

- No space constraints or color figure charges

- Immediate publication on acceptance

- Inclusion in PubMed, CAS, Scopus and Google Scholar

- Research which is freely available for redistribution

Submit your manuscript at www.biomedcentral.com/submit
(Ciomed Central 